\title{
Rich-grain-boundary PtRuNi with network structure as efficient catalysts for methanol oxidation reaction
}

\author{
Zi-ning Wang, Shu-hui Huo*, Peng-xin Zhou* \\ College of Chemistry and Chemical Engineering, Northwest Normal University, Lanzhou 730070, \\ China \\ *E-mail: huosh_2000@163.com, zhoupx@nwnu.edu.cn
}

doi: $10.20964 / 2019.11 .49$

Received: 3 July 2019 / Accepted: 8 September 2019 / Published: 7 October 2019

\begin{abstract}
Fabricating a network structure is an efficient way to increase the electrocatalytic activity of a catalyst. In this study, a network-like structure of PtRuNi with rich grain boundaries characterized via scanning electron microscopy and transmission electron microscopy was prepared by an electrochemical dealloying process. For methanol oxidation, PtRuNi networks show an onset potential of $0.40 \mathrm{~V}$ with a mass activity of $220 \mathrm{~mA} \mathrm{mg}_{\mathrm{Pt}}{ }^{-1}$ for methanol oxidation. The good catalytic activity of PtRuNi networks could be ascribed to the unique structure of a net framework with rich grain boundaries.
\end{abstract}

Keywords: PtRuNi; Nanoparticle; Catalyst; Direct methanol fuel cell.

\section{$\underline{\text { FULL TEXT }}$}

(C) 2019 The Authors. Published by ESG (www.electrochemsci.org). This article is an open access article distributed under the terms and conditions of the Creative Commons Attribution license (http://creativecommons.org/licenses/by/4.0/). 